\title{
Utilization of Biofloc System Catfish Pond Waste Nutrients in the Cultivation of Kale, Spinach, Pakcoy, and Lettuce Using the Aquaponic System
}

\author{
I Gusti Nyoman Arthanawa *1, I Nyoman Astiko *, Dewa Putu Semara Yana *, \\ I Ketut Darmawan *, Yohanes Parlindungan Situmeang **2, I Dewa Nyoman Sudita ** \\ * Students of the Masters in Agricultural Science Study Program, Postgraduate Program, \\ Warmadewa University, Denpasar-Bali, Indonesia \\ ** Lecturer at the Masters in Agricultural Science Study Program, Postgraduate Program, \\ Warmadewa University, Denpasar-Bali Indonesia. \\ 1 arthanawa78@gmail.com \\ 2 ypsitumeang63@gmail.com
}

\begin{abstract}
The cultivation of catfish using the biofloc system produces waste in the form of remaining ponds that can be used for aquaponic farming systems. The combination of fermentation between catfish waste and chicken manure affects the growth of kale, lettuce, pakcoy, and spinach with an aquaponic system. This research was conducted in the ALC (Agro Learning Center) garden in collaboration with the Master of Agricultural Science Study Program, Postgraduate Program of Warmadewa University. The parameters observed were plant height, number of leaves, fresh weight, and oven-dry weight. The best results for plant height are found in spinach plants. The best number of leaves is found in pakcoy plants. As for fresh weight and dry weight, the best results were on pakcoy plants. The best concentration of the combination of catfish waste fermentation with chicken manure is at a concentration of 1400 ppm.
\end{abstract}

Keyword: Catfish waste, biofloc system, aquaponics, hydroponic vegetables

\section{Introduction}

Aquaponics is a combination of aquaculture (fish farming) and hydroponic cultivation of plants in one place. The basic principle of aquaponics is that it can be done at the same time by utilizing fish waste and fish food waste as a source of nutrition for cultivated plants [1]. According to [2] that with an aquaponic system, the absorption of nutrients from fish waste is more effective, thereby increasing crop production. Biofloc is a collection of various types of organisms such as fungi, bacteria, algae, protozoa, worms, etc., which are combined in clumps. Biofloc technology or activated sludge is the adoption of activated sludge biological treatment technology using the activity of microorganisms to increase carbon and nitrogen [3]. Catfish (Clarias sp.) Is one type of fish that has economic value, is easy to maintain, and can grow quickly. This potential encourages community interest to increase production through intensive cultivation [4]. This catfish waste can reduce water conditions and hurt behavior, physiological processes, growth, and mortality of fish. Catfish wastewater which contains organic material will be used by plants as a source of nutrition for their growth. According to [5], aquaculture wastewater containing organic matter will be utilized by plants as nutrients for growth. Chicken manure has a fairly high $\mathrm{N}$ content, compared to other animal manure, and a low $\mathrm{C} / \mathrm{N}$ ratio. The relatively high $\mathrm{N}$ content in chicken manure can be used to meet the nutrient needs of lettuce. In addition, the addition of solid fertilizer for chicken manure is also able to improve the physical properties of the soil. However, solid chicken manure is generally available slower to plants, because it takes time for the decomposition process [6]. This study used 4 types of vegetables, namely kale, lettuce, pakcoy, and spinach. The purpose of this study was to 
determine the response to the growth and yield of various types of vegetables at different concentrations of the biofloc system catfish waste solution mixed with chicken manure.

\section{Material and Methods}

The research was conducted at the location of the biofloc system catfish ponds on Jalan Cekomaria Denpasar Bali. This aquaponic research is a collaboration between the Agro Learning Center (ALC) and the Master of Agricultural Science Study Program, Postgraduate Program, Warmadewa University. The research took place from January to February 2021. The tools used were hydroponic installation, biofloc system catfish pond, fermentation pond, pool water pump machine, and knife. The materials used are kale, lettuce, pakcoy, and spinach seeds, catfish waste, chicken manure, Rockwool.

This study used a completely randomized design (CRD) with a factorial pattern (two factors) with 4 replications. The first factor is the treatment of various types of vegetables (Kangkung, Spinach, Pakcoy, and Lettuce), while the second factor is the concentration of the biofloc system catfish waste solution (1000 ppm and $1400 \mathrm{ppm})$. From this arrangement of treatments obtained 8 treatment combinations and 32 experimental units.

Water spinach, lettuce, pakcoy, and spinach were planted on Rockwool media and after 7 days they were ready to be moved or planted in aquaponic installations and their progress was observed. To get nutrients concentrations of 1000 and $1400 \mathrm{ppm}$, catfish waste and chicken manure were homogenized in 1 pond and fermented for 7 days then the nutrient levels were adjusted so that they could reach concentrations of $1000 \mathrm{ppm}$ and $1400 \mathrm{ppm}$.

The variables observed in this study were plant height, number of leaves, plant fresh weight, and plant oven-dry weight. Observation of plant height and the number of leaves was carried out at the age of 1,2, and 3 weeks after planting (wap). Meanwhile, plant fresh weight was observed at harvest time ( 5 weeks old), and dry weight was carried out by oven fresh weight at $85{ }^{\circ} \mathrm{C}$ until the weight was constant. The test method was carried out by analysis of variance. If the treatment that was tried showed a significant effect, then a further test was carried out using the LSD level of 5\%.

\section{Results and Discussion}

Based on the observations obtained, the growth of vegetable plants shows good development from week to week. The results of plant height observations obtained from this study can be seen in Table 1, Figures 1 and 2).

Table 1

Effect of Treatment of Catfish Waste Nutritional Concentration on Plant Height.

\begin{tabular}{lccc}
\hline Treatment & $\begin{array}{c}\text { Plant Height } \\
1 \text { wap } \\
(\mathrm{cm})\end{array}$ & $\begin{array}{c}\text { Plant Height } \\
2 \text { wap } \\
(\mathrm{cm})\end{array}$ & $\begin{array}{c}\text { Plant Height } \\
3 \text { wap } \\
(\mathrm{cm})\end{array}$ \\
\hline Types of Vegetables & & & \\
Kale & $23.32 \mathrm{a}$ & $34.87 \mathrm{a}$ & $50.12 \mathrm{a}$ \\
Spinach & $16.70 \mathrm{~b}$ & $30.92 \mathrm{a}$ & $50.16 \mathrm{a}$ \\
Pakcoy & $18.28 \mathrm{~b}$ & $23.03 \mathrm{~b}$ & $24.88 \mathrm{~b}$ \\
Lettuce & $9.64 \mathrm{c}$ & $13.72 \mathrm{c}$ & $20.89 \mathrm{~b}$ \\
\hline LSD 5\% & 3.54 & 5.64 & 7.76 \\
\hline The concentration of Waste Nutrition & & & \\
1000 ppm & $17.46 \mathrm{a}$ & $25.67 \mathrm{a}$ & $36.18 \mathrm{a}$ \\
$1400 \mathrm{ppm}$ & $16.51 \mathrm{a}$ & $25.60 \mathrm{a}$ & $36.84 \mathrm{a}$ \\
\hline LSD 5\% & - & &
\end{tabular}

Note: The same lowercase letters on the same factors are not significantly different in the 5\% LSD test. 


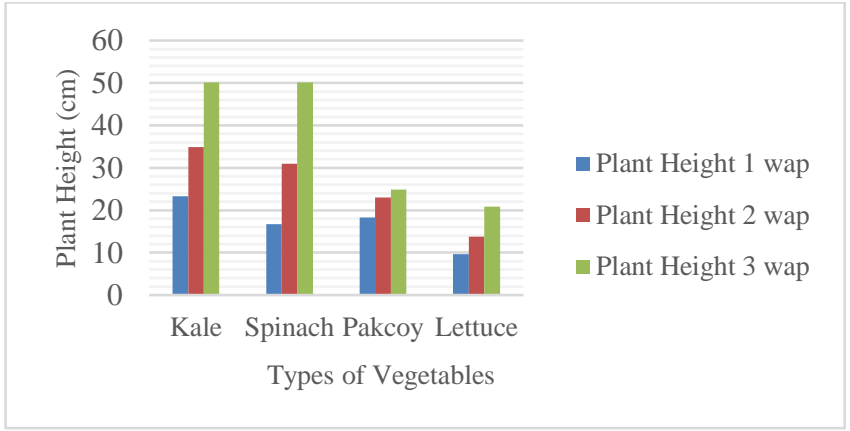

Figure 1

Plant height growth 1,2, and 3 weeks after planting on various types of vegetables

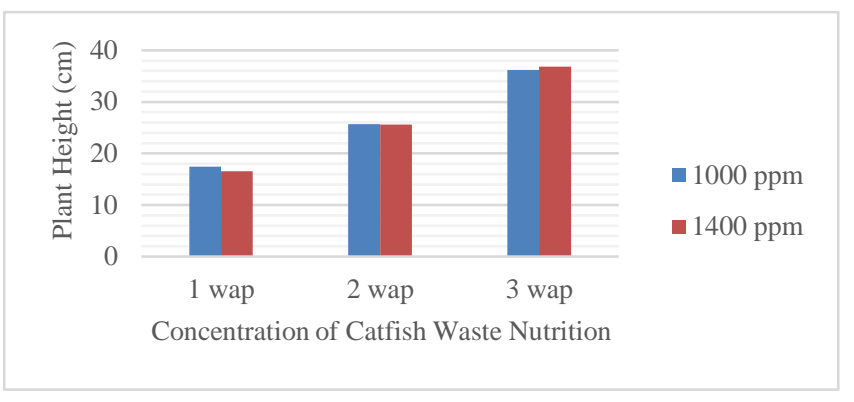

Figure 2

Plant height growth 1,2, and 3 weeks after planting at different concentrations of catfish waste nutrients

In the observation of plant height, there was a significant difference between varieties. This shows that plants show a different response to a given nutrient. In addition, the type of plant also affects the response of these plants. In the observation of plant height, there was an increase in plant height every week. From the observations of plant height, the $\mathrm{N}$ element is very influential so that plant growth is very optimal. According to [7], the fish waste contains $2.26 \% \mathrm{~N}$ nutrient. Elemental $\mathrm{N}$ is very important for the vegetative growth of plants. This is by research [8] that aquaponic treatment increases plant height. Plant growth is influenced by various factors, namely the intensity of sunlight, the temperature in the root area, ambient temperature, $\mathrm{pH}$, nutrient concentration, and the type of plant [9]. In observing the treatment concentration, there was no significant difference between the concentrations given. Furthermore, the growth in the number of leaves aged 1, 2, and 3 weeks after planting in the treatment of various types of vegetables and nutrient concentrations from catfish pond waste with the biofloc system can be seen in Table 2, Figures 3 and 4).

Table 2

Effect of Treatment of Catfish Waste Nutritional Concentration on Number of Plant Leaves

\begin{tabular}{lccc}
\hline Treatment & $\begin{array}{c}\text { Number of Leaves } \\
\text { 1 wap } \\
\text { (strands) }\end{array}$ & $\begin{array}{c}\text { Number of Leaves } \\
\text { 2 wap } \\
\text { (strands) }\end{array}$ & $\begin{array}{c}\text { Number of Leaves } \\
\text { 3 wap } \\
\text { (strands) }\end{array}$ \\
\hline Types of Vegetables & & & \\
Kale & $18.16 \mathrm{a}$ & $36.72 \mathrm{a}$ & $107.75 \mathrm{~b}$ \\
Spinach & $11.31 \mathrm{~b}$ & $25.69 \mathrm{c}$ & $108.21 \mathrm{~b}$ \\
Pakcoy & $14.75 \mathrm{ab}$ & $33.03 \mathrm{~b}$ & $262.00 \mathrm{a}$ \\
Lettuce & $7.72 \mathrm{~b}$ & $13.97 \mathrm{~d}$ & $66.28 \mathrm{~b}$ \\
\hline LSD 5\% & 4.70 & 3.44 & 48.92 \\
\hline The concentration of Waste Nutrition & & & $129.73 \mathrm{a}$ \\
$1000 \mathrm{ppm}$ & $21.09 \mathrm{~b}$ & $27.47 \mathrm{a}$ & $142.39 \mathrm{a}$ \\
\hline $1400 \mathrm{ppm}$ & $4.88 \mathrm{a}$ & $27.23 \mathrm{a}$ & -
\end{tabular}

Note: The same lowercase letters on the same factors are not significantly different in the 5\% LSD test 


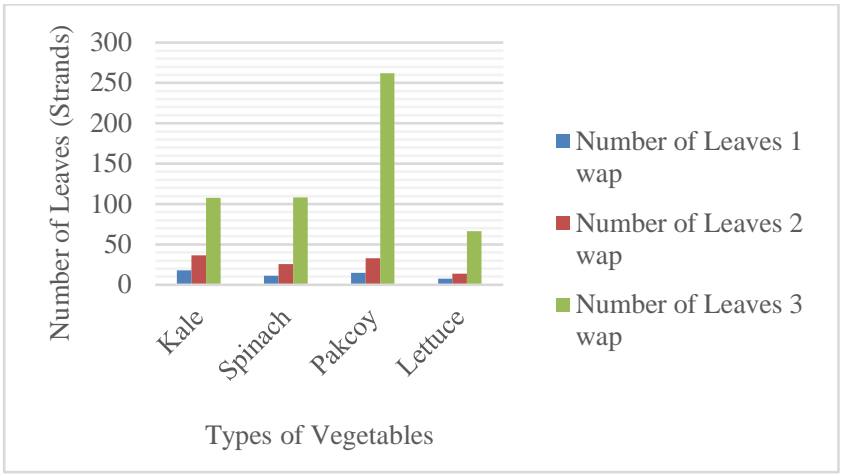

Figure 3

Growth in the number of leaves 1,2, and 3 weeks after planting in the treatment of various types of vegetables

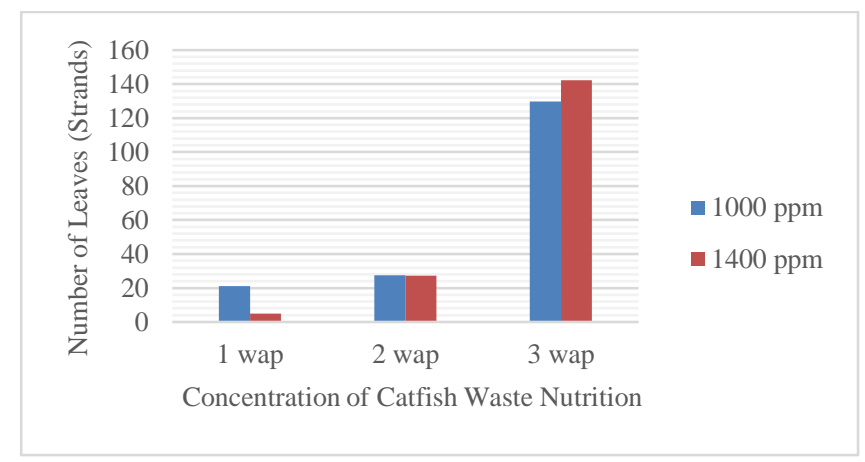

Figure 4

Growth in the number of leaves aged 1,2, and 3 weeks after planting at different catfish waste nutrient treatment concentrations

In observing the number of leaves, there was a significant difference between plant varieties. This shows that the combination of catfish waste and chicken manure has a significant effect on the number of leaves from plants. According to [10] an increase in plant height can support an increase in the number of leaves as the plant ages. In addition, according to [11], chicken manure contains complete nutrients so that it can spur the growth of plant leaves. This is supported by a statement from [12] which states that the available $\mathrm{N}$ element from catfish waste can increase photosynthetic yield and in turn can affect plant growth and development. Apart from observing plant growth, wet weight and oven-dry weight were also observed. The results of fresh weight on the treatment of various types of vegetables and nutrient concentrations of catfish pond waste with the biofloc system are shown in Table 3, Figures 5 and 6).

Table 3

Effect of Catfish Waste Concentration Treatment on Fresh Weight and Oven Dry Weight

\begin{tabular}{ccc}
\hline Treatment & $\begin{array}{c}\text { Fresh Weight } \\
(\mathrm{g})\end{array}$ & $\begin{array}{c}\text { Oven Dry Weight } \\
(\mathrm{g})\end{array}$ \\
\hline Types of Vegetables & & \\
Kale & $107.75 \mathrm{~b}$ & $8.58 \mathrm{~b}$ \\
Spinach & $108.21 \mathrm{~b}$ & $8.44 \mathrm{~b}$ \\
Pakcoy & $262.00 \mathrm{a}$ & $13.39 \mathrm{a}$ \\
Lettuce & $66.28 \mathrm{~b}$ & $2.90 \mathrm{c}$ \\
\hline LSD 5\% & 48.92 & 4.35 \\
\hline The concentration of Waste Nutrition & & \\
\hline 1000 ppm & $129.73 \mathrm{a}$ & $7.90 \mathrm{a}$ \\
1400 ppm & $142.39 \mathrm{a}$ & $8.76 \mathrm{a}$ \\
\hline LSD 5\% & - & - \\
\hline
\end{tabular}

Note: The same lowercase letters on the same factors are not significantly different in the 5\% LSD test 


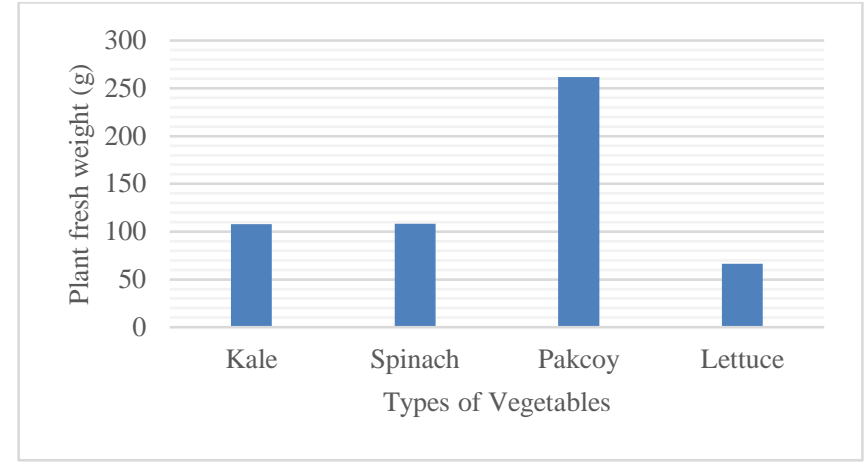

Figure 5

Fresh planting weight at harvest in the treatment of various types of vegetables of vegetables

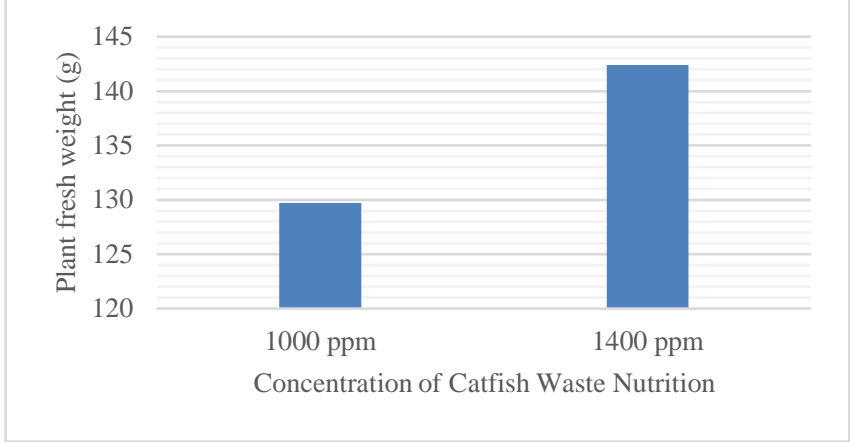

Figure 6

Plant fresh weight at harvest at the different treatment of catfish waste nutrient concentrations

In observing fresh weight, there is a significant difference between varieties as shown in the table above. Pakcoy had the highest fresh weight, 262.00 grams, while lettuce had the lowest fresh weight, 66.28 grams. This can happen because in one net pot the pakcoy plant has 4-6 vegetable stalks which result in the pakcoy plant having the highest weight. While lettuce has the smallest weight because of the arrangement of the lettuce plant in the form of widened leaves which results in the lettuce having the lowest weight. Increasing the number of plant leaves will increase the fresh weight [13]. In line with fresh weight, Pakcoy oven-dry weight has the highest weight with 13.39 grams while lettuce has the lowest weight with 2.90 grams. At a concentration of $1000 \mathrm{ppm}$, the average plant fresh weight was 129.73 grams, while at a concentration of $1400 \mathrm{ppm}$ the average plant fresh weight had a higher fresh weight yield of 142.39 grams.

\section{Conclusion}

Based on these results, it can be concluded that kale, lettuce, pakcoy, and spinach can grow well in the aquaponics system with nutrients that come from a combination of catfish waste and chicken manure. Pakcoy has the highest fresh weight while lettuce has the lowest fresh weight. The highest average plant fresh weight was at a concentration of $1400 \mathrm{ppm}$ with 142.39 grams.

\section{Acknowledgments}

The author would like to thank the managers of the Agro Learning Center for their cooperation and the lecturers who have accompanied and guided us during the research until the writing of this article was completed well. 


\section{References}

[1] Nugroho, R.A., Pambudi, L.T., Chilmawati, D. dan Haditomo, A.H.C. (2012). Aplikasi teknologi aquaponic pada budidaya ikan air tawar untuk optimalisasi kapasitas produksi. Saintek Perikanan, 8 (1): 46-51.

[2] Rokhmah, N.A., Ammatillah, C.S., dan Sastro, Y. (2014). Vertiminaponik, mini akuaponik untuk lahan sempit di perkotaan. Buletin Pertanian Perkotaan, 4 (2): 14-22.

[3] Suprapto, Samtafsir SL, (2013). Bioflok-165 Rahasia Sukses Teknologi Budidaya Lele, Depok (ID): AGRO 165.

[4] Ciptanto S. (2010). Top 10 ikan air tawar, panduan lengkap pembesaran secara organik di kolam airterpal, karamba, dan jala apung.Yogyakarta: Lyly Publisher.

[5] Effendi, H., Utomo, B.A., Darmawangsa, G.M. (2015). Phytoremediation of Freshwater Crayfish (Cherax quadricaarinatus) culture wastewater with spinach (Ipomoea aquatic) in the aquaponic system. Aquaculture, Aquarium, Conservation and Legislation International, Journal of the Bioflux Society. 8(3): 421-430.

[6] Hardjowigeno. S. H. (2007). Ilmu tanah. Akademika Pressindo, Jakarta.

[7] Aditya,S., Suparmi, dan Edison. (2015). Studi pembuatan pupuk organik padat limbah perikanan. JOM. Vol.2 No. 2.

[8] Nugroho, R.A., Pambudi, L.T., Chilmawati, D. dan Haditomo, A.H.C. (2012). Aplikasi teknologi aquaponic pada budidaya ikan air tawar untuk optimalisasi kapasitas produksi. Saintek Perikanan, 8 (1): 46-51.

[9] Buzby KM, Lian Shin L. (2014). Scaling aquaponic systems: balancing plant uptake with fish output. Aquaculture Engineering. 63:39-44.

[10] Utami, S. (2005). "Pengaruh Sistem Olah Tanah Terhadap Pertumbuhan dan Hasil Jagung Manis (Zea mays Saccharata Strurt)". Skripsi. Fakultas Pertanian Universitas Muhammadiyah Yogyakarta, Yogyakarta.

[11] Darmawan, A. F., N. Herlina, R. Soelistyo. (2013). Pengaruh berbagai macam bahan organik dan pemberian air terhadap pertumbuhan dan hasil tanaman sawi (Brassica juncea L.). Jurnal Produksi Tanaman Vol.1 No.5.

[12] Rahmadhani, L.E., L.I. Widuri, P. Dewanti. (2020). Kualitas mutu sayur KASEPAK (Kangkung, Selada, dan Pakcoy) dengan sistem budidaya akuaponik dan hidroponik. Jurnal Agroteknologi Vol.14 No.01.

[13] Polii, M.G.M. (2009). Respon produksi tanaman kangkung terhadap variasi waktu pemberian pupuk kotoran ayam. Soil Environment, 1 (7): 18-22. 